\title{
Uma vida dedicada ao combate do racismo na Amazônia: entrevista com Zélia Amador de Deus, por ocasião de seus 70 anos
}

\section{A life dedicated to combating racism in the Amazon: interview with Zélia Amador de Deus, on her 70th birthday}

Alef Monteiro - Mestrando no Programa de Pós-Graduação em Sociologia e Antropologia, da Universidade Federal do Pará (UFPA). Apoio CAPES. E-mail: alefmonteiro1@gmail.com

\section{Resumo}

Em2019,Zélia Amador de Deus completou 70 anos de vida. E, no mês de abril desse mesmo ano, encontramo-nos na sala do Grupo de Estudos Afro-Amazônico da Universidade Federal do Pará, a fim de conversar sobre sua trajetória pessoal e acadêmica. Isto posto, apresento aqui uma síntese de nosso diálogo. Meu objetivo é apresentar flashs da biografia de Zélia, à luz de sua própria memória, e revelar algumas avaliações e perspectivas da intelectual tanto sobre o Movimento Negro, quanto sobre os estudos acerca das populações afroamazônicas na atualidade. $\mathrm{O}$ método utilizado foi a entrevista semiestruturada. Ao final da entrevista, concluo que a vida e o pensamento de Zélia são singulares para a defesa dos direitos das populações negras no Norte do Brasil, ao mesmo tempo que embasam a construção de uma identidade afroamazônica nos espaços acadêmicos e de militância política.

\begin{abstract}
In 2019, Zélia Amador de Deus completed 70 years of life. And, in April of that same year, we met in the room of the AfroAmazonian Study Group at the Federal University of Pará, in order to talk about his personal and academic trajectory. That said, I present here a synthesis of our dialogue. My objective is to present flashes of Zélia's biography, in the light of her own memory, and to reveal some evaluations and perspectives of the intellectual both on the Black Movement and on studies about Afro-Amazonian populations today. The method used was the semi-structured interview. At the end of the interview, I conclude that Zélia's life and thought are unique for the defense of the rights of black populations in Northern Brazil, while supporting the construction of an Afro-Amazonian identity in academic and political militancy spaces.
\end{abstract}

\section{Keywords}

Zélia Amador de Deus. Life trajectory.

Black Movement. Anti-racism.
Zélia Amador de Deus. Trajetória de vida. Movimento Negro. Antirracismo. 


\section{INTRODUÇÃO}

No dia 24 de outubro de 2019, Zélia Amador de Deus completou 70 anos de vida. Sourense ${ }^{1}$ de nascimento e belenense por vivência, Zélia é considerada, na atualidade, a intelectual negra mais importante da Região Norte do país, tendo sido a escritora homenageada na $23^{\text {a }}$ Feira Pan-Amazônica do Livro e das Multivozes (maior evento literário da Pan-Amazônia), evento realizado nos meses de agosto e setembro de 2019, na cidade de Belém do Pará, Brasil. O reconhecimento de Zélia, porém, não é de hoje, em 2014 ela foi a intelectual negra homenageada no VIII Congresso Nacional de Pesquisadores/as Negros/as, realizado bianualmente pela Associação Brasileira de Pesquisadores/as Negros/as (ABPN), instituição que reúne o maior número de intelectuais negros do país e que foi presidida por Zélia Amador de Deus entre os anos de 2010 e 2012.

Dona de uma trajetória eclética construída no encontro entre as Artes Cênicas, as Letras e as Ciências Sociais, a marca de Zélia é a junção que faz entre a excelência acadêmica e a militância. Dentro e fora da universidade, o nome Zélia Amador de Deus é referência nas discussões e ações que abrangem os direitos das populações negras, o Movimento Negro, ações afirmativas, questões étnicoraciais, arte, educação, literatura negra e outros aspectos da negritude amazônica. O que não poderia ser diferente, a história de Zélia é parte inseparável da história do movimento negro brasileiro, da luta junto ao Estado e instituições afins, em prol da garantia dos direitos das populações afro amazônicas e suas culturas, da luta contra o racismo no meio acadêmico, com destaque à conquista de cotas raciais para negros nas universidades e, mais especificamente, na Universidade Federal do Pará (UFPA).

Por ainda não ser nacionalmente conhecida como deveria, acho importante elencar mais alguns de seus feitos: Zélia foi uma das fundadoras do Centro de Estudos e Defesa do Negro do Pará (CEDENPA) - maior e mais antiga célula do movimento negro na Região Norte. Entre os anos de 1980 e 1990 atuou, via CEDENPA, junto às comunidades quilombolas do Pará, em prol do reconhecimento e titulação dos quilombos. No meio acadêmico, Zélia exerce, há mais de quarenta anos, a função de professora (atualmente emérita) da UFPA, instituição da qual também foi vice-reitora e é a atual assessora de diversidade e inclusão social. Ainda na UFPA, no ano de 2002, junto com outros professores e discentes, fundou o primeiro Núcleo de Estudos Afro-Brasileiros (NEAB) da região Norte do país - o Grupo de Estudos Afro-amazônico (GEAM/UFPA),

Zélia nasceu no território quilombola de Mangueiras, que hoje faz parte do município de Salvaterra, mas na época de seu nascimento era município de Soure. 
e também a Casa Brasil-África, órgão universitário destinado à produção e divulgação de conhecimento sobre os países africanos, e também à firmação de parcerias entre a UFPA e universidades africanas. Em 2001, Zélia foi uma das representantes do Brasil na Conferência de Durban, da Organização das Nações Unidas $(\mathrm{ONU})^{2}$. E, apesar de já defender essa pauta desde a abertura política do Brasil, com o parecer favorável da ONU, após Durban, Zélia encabeçou a luta pelas ações afirmativas para negros na UFPA - tema sobre o qual escreveu uma tese de doutorado.

Meus caminhos se cruzaram com os de Zélia em março de 2013, quando ingressei no GEAM, sob a condição de bolsista. Na época, eu estava cursando o terceiro semestre de minha graduação em Ciências Sociais. Ganhei a bolsa do GEAM por uma faceta do destino: o rapaz que ocupava a vaga antes de mim conseguiu uma outra bolsa para trabalhar com sua orientadora, e, como eu já andava pelo GEAM desde o final de 2012, em busca da orientação da Prof. ${ }^{a}$ Dr. ${ }^{a}$ Marilu Campelo, eminente estudiosa das religiões de matriz africana na Amazônia, o próprio colega lembrou de mim e fez minha indicação para ocupar a vaga deixada por ele.

Rapidamente fui acolhido por todos e passei a trabalhar assistindo as atividades acadêmicas, extensionistas e administrativas do GEAM. Conviver nesse grupo marcou, consideravelmente, minha formação humana e intelectual. Com meus colegas discentes e os professores, ganhei consciência das implicações da Diáspora Africana na cultura e nas socialidades da sociedade brasileira; aprendi a valorizar a produção científica compromissada com a melhoria da qualidade de vida das populações subalternizadas; e entendi que a militância acadêmica é uma consequência inexorável do fazer científico pleno.

Dentre meus principais mentores, aquela senhora negra de cabelo black, roupas estampadas, cigarros sempre que possível à mão, e com uma voz fortalecida pelo tom grave e eloquente, logo ganhou espaço de destaque. Sem dúvida, Zélia influenciou (e ainda influencia) toda a minha geração de pesquisadores formados pelo GEAM, em quase vinte anos de existência do NEAB. Devido nossa proximidade, posso dizer que tal qual o trabalho de Davi Kopenawa e Bruce Albert (2015), há entre mim e Zélia, no texto que ora ofereço, um pacto político e etnobiográfico. Somos estudiosos do mesmo espectro temático (as populações afro brasileiras/afro amazônicas), militamos pelas mesmas causas e temos um laço de amizade. E, mais que isso, consideramos importante usar da sagacidade

Terceira Conferência Mundial contra o Racismo, a Discriminação Racial, a Xenofobia e Formas Correlatas de Intolerância promovida pela ONU. Por ter sido realizada na cidade de Durban, na África do Sul, o encontro é geralmente conhecido simplesmente como "Conferência de Durban". 
de Ananse ${ }^{3}$ para recontar a história da população negra no Brasil, erigindo marcos substanciados em eventos e personalidades. Zélia é uma personalidade negra cuja trajetória ergo como memorial, em que a presente entrevista, que aborda sua trajetória de vida pessoal e acadêmica, é um retalho de grande semióforo.

Para produzir este texto, realizei uma entrevista semiestruturada, a partir de um roteiro composto por nove perguntas, que julguei pertinentes para se conhecer, panoramicamente, o percurso biográfico de Zélia. O instrumento de registro foi o aplicativo de gravação de voz do meu celular e de colegas que estavam presentes na sala do GEAM, no dia da entrevista. Não teço qualquer consideração sobre as opiniões da entrevistada, nem tento explicar o que ela diz. Influenciado por Spivak (2010), tento não ser aquele intelectual que julga saber sobre o entrevistado mais do que ele próprio. É certo que editei as respostas de Zélia, pois, enredados por longos parênteses e devaneios típicos da intimidade, conversamos por horas. Entretanto, ao assumir o papel de editor, tentei ser cúmplice da entrevistada, no mesmo feitio de Bruce Albert (KOPENAWA; ALBERT, 2015).

Preservo no registro escrito às peculiaridades da fala que, não raramente, burlam as regras da gramática canônica. Gentilmente, peço licença e explico, que essa manutenção é necessária porque a entrevistada, de modo proposital e contra hegemônico, mistura o português culto ao pretuguês ${ }^{4}$, de sorte que eliminar essa originalidade de Zélia (e de boa parte dos intelectuais negros), na transcrição de sua fala, seria cometer uma violência linguística. Além disso, compartilho com Zélia a convicção da necessidade de falar em outras "línguas"; "línguas" que, como explica Anzaldúa (2000), rompam com a linguagem hermética e colonizada que predomina na Academia. Conforme a metáfora também de Anzaldúa (2009), a língua de Zélia é uma "língua selvagem", e essa "selvageria" tentei, a todo custo, preservar na transcrição de sua oralidade.

Posto isso, apresento a todas e todos, especialmente aos interessados pela história do movimento negro na Região Norte do Brasil; aos pesquisadores das populações afro brasileiras/afro amazônicas; e às populações negras em geral, uma versão da trajetória de Zélia, e algumas avaliações e perspectivas que ela possui sobre o Movimento Negro e sobre os estudos acerca das populações afro amazônicas. Nosso diálogo ocorreu no dia 01 de abril de 2019, na sala do

3 Ananse é o deus-aranha da cultura fanti-ashanti, conhecido por completar as tarefas dadas por Nyame, deus do céu. O prêmio recebido foram todas as histórias do mundo. Ananse conseguiu cumprir as tarefas graças à sua capacidade de tecer histórias-teias com as quais enredou e prendeu aqueles a quem precisava capturar (AMADOR DE DEUS, 2019).

4 Lélia Gonzáles (1984) chama de pretuguês a variação linguística da língua portuguesa, cotidianamente usada no vernáculo brasileiro, formada pela herança do vocabulário e da prosódia das várias etnias africanas que compuseram a população do país. 
GEAM, na UFPA - espaço escolhido por Zélia, e foi realizado sob os auspícios do septuagésimo aniversário da intelectual, que ocorreu seis meses depois. Vejamos, então, o que Zélia disse em nosso encontro.

Alef Monteiro: Professora, conte-nos, panoramicamente, a sua trajetória de Soure (atual Salvaterra) a Belém.

Zélia Amador de Deus: Eu cheguei a Belém muito cedo, eu tinha um ano, um ano e meio, por aí... Minha família veio morar em Belém, porque a minha mãe engravidou adolescente, ela tinha 15 anos quando eu nasci. Aí a minha avó ficou muito desgostosa, minha mãe era filha única, então resolveu vir embora pra cá, porque ela queria que eu estudasse, esse era o sonho. Eu tinha que estudar pra não ter a mesma sina. Aí ela veio pra cá, meteu na cabeça que tinha que vir, e veio todo mundo. E eu era muito pequena e já me entendi aqui na Sacramenta, que era o fim de Belém. A Sacramenta não tinha água encanada, não tinha luz elétrica, me lembro que a luz elétrica chegou à Sacramenta em 1960. Enfim, não tinha nada, era quase mata. E eu me criei lá, me entendo já morando na Sacramenta.

A minha mãe não tinha completado dezoito anos quando começou a trabalhar como empregada doméstica. Aí, depois que ela completou dezoito anos, tinha períodos que ela trabalhava na fábrica de castanha, que empregava em regime sazonal, então ela trabalhava um tempo, aí davam baixa na carteira e ela voltava a trabalhar no emprego doméstico. A gente vivia de salário-mínimo e meu avô era a principal fonte do nosso sustento porque a minha mãe ganhava muito pouco e dava praticamente só pra ela, a minha avó também ganhava pouco lavando roupa pra fora. Logo, ele é quem trabalhava pra arcar com a maior parte dos gastos da casa. Ele era semianalfabeto, e fazia de tudo. Apesar da baixa escolaridade, ele conseguiu um emprego como escavador aqui na Companhia de Saneamento que estava saneando Belém naquele momento. O nome da empresa era Byington, o mesmo sobrenome da Olivia Byington, mas para o povo era "Baita", então eu também chamava de "Baita" e só mais tarde é que eu descobri que a "empresa Baita" era Byington.

E aí depois eu fiquei estudando por ali, a minha avó me colocou pra estudar muito cedo no externato bem de fronte de onde eu morava, eu tinha uns seis, sete anos. E era uma sala que a professora tinha alunos da alfabetização, primeira, segunda, terceira e quarta série. Era o que hoje a gente chama de turma multisseriada. Lembro que no dia que eu ouvi, na graduação, alguém falando contra turmas multisseriadas, eu levei um susto porque, pra mim, tinha sido uma experiência muito boa. Como eu era uma criança muito observadora, eu aprendia 
tudo. Quando eu saí de lá eu tinha terminado a alfabetização e o primeiro ano, mas eu já sabia tudo, fazer conta de dividir, de somar, de multiplicar, eu fiquei muito boa em matemática, eu era "a fera" em matemática.

E aí eu fui estudar no Instituto Catarina Labouré, que ainda está lá na Sacramenta até hoje. Lá eu entrei no terceiro ano, já. A freira descobriu que eu era "fera" em matemática e ela me colocava como sua monitora ensinando matemática para as minhas colegas que tinham dificuldade, e eu não conseguia entender como alguém tinha dificuldade em matemática, era a coisa que eu mais gostava no mundo, eu adorava! Mas eu fiquei ajudando ela um tempo.

Depois do Catarina, eu fui pro IEP [Instituto de Educação do Pará], que, naqueles tempos, era a Escola Normal. Fiz a admissão e entrei porque tive que fazer um curso que eu tivesse logo resposta de emprego, porque nossa situação financeira era muito difícil. E, como não tínhamos dinheiro. Eu morava longe da escola e tive que trabalhar pra conseguir o dinheiro pra pagar as minhas passagens de ônibus. Eu estudava, portanto, na Escola Normal, e, como eu sempre cozinhei muito bem, eu fazia a comida da minha vizinha, eu estudava de tarde, ela me pagava e aquele era o meu dinheiro do ônibus. Eu dava aula de matemática pra tudo quanto é criança que tivesse dificuldade e recebia também por isso, nisso eu tinha doze, treze anos e eu já estava dando aula particular e eu recebia pra poder ter dinheiro pra ir à escola. Eu fazia um feijão muito bom, e ainda faço, mas naquele tempo eu fazia por necessidade, hoje eu só faço por prazer. Eu fazia e a vizinha me pagava e, com isso, eu tinha aquele dinheirinho pra ir pra escola. E assim eu fui levando a vida e consegui concluir o meu primeiro e segundo grau, meu avô trabalhando sempre, e a gente muito, muito pobre, também trabalhando para se manter.

Alef Monteiro: Como foi a experiência de reconhecimento e afirmação da sua negritude?

Zélia Amador de Deus: Eu sempre soube que eu era preta! Vejo muitas mulheres negras narrando como se descobriram negras, mas comigo não foi assim. Eu já sabia, por que minha avó me dizia o tempo inteiro, ela não me enganava, e, na escola, uma freira me disse da pior maneira possível. Também tinha a molecada que me chamava o tempo todo de "Preta do Batuque", "Preta da Macumba", então, quem é que não vai saber?! Agora, a afirmação da minha negritude veio mais tarde. Porém, essa afirmação que veio mais tarde foi a consequência da junção daquilo que eu aprendi ainda criança, através dos ensinamentos da minha avó, e a formação política que eu fui construindo em minha trajetória de vida. 
Em casa, minha avó sempre me dizia: “tu és preta, mas tu não és inferior!”. Eu aprendi muito isso, então, isso para mim tá marcado até hoje: "Não deixa ninguém te tratar mal porque tu não és inferior e se te chamarem de preta tu dizes 'sou, mas não sou da tua cozinha!"' [Risos]. Era assim que ela me ensinava. E ela me ensinou uma coisa que às vezes eu nem conto, ela dizia que se eu notasse que alguém estivesse querendo ser superior a mim, era pra eu olhar bem na cara, encarar essa pessoa e imaginá-la nas mesmas situações que as minhas. Ela dizia: “come igual a ti, descome igual a ti, então não é superior!", aí eu olhava; até hoje eu ainda olho. Quando eu chego junto a certas pessoas que são verdadeiros reis da arrogância, a minha técnica vem de lá. Eu olho essas pessoas bem na cara e imagino elas com dor de barriga, com diarreia no banheiro... [Risos]. Acabou, não tem arrogância certa, acabou, é igual a mim, sente tudo igual.

Essa minha postura insubmissa que eu construí, em parte, já na minha casa, foi tomando corpo com o tempo conforme eu adquiri consciência das coisas que se davam ao meu redor. Eu sempre fui insatisfeita com várias coisas e essa minha insatisfação me levou ao envolvimento com muitos movimentos. Desde cedo eu comecei a participar de movimentos, tá?! Primeiro eu entrei na Cruzada [Mariana], eu era cruzadinha, lá no colégio. Depois eu entrei no grupo de jovens lá da Paróquia São Sebastião, na Sacramenta, quando eu fui crescendo. Nessa época chegou um padre lá pra paróquia, um holandês, que ele era da Teologia da Libertação, e aí ele organizava os grupos de jovens e eu entrei, porque já era o que eu queria: questionar várias coisas a fim de dizer o que nos acontecia e o que a gente estava sentindo.

Lembro que ele fazia uns presépios de denúncia (a gente estava vivendo a ditatura) e eu participava da elaboração e confecção desses presépios. Comecei a trabalhar com papel machê nesse momento. Eu trabalhava fazendo figuras e eram figuras de denúncia da situação política. Depois eu me envolvi no Movimento Estudantil Secundarista - estou dando um painel rápido, tá?! As coisas estão correndo muito rápido - eu terminei a quinta série lá no Catarina Labouré, e de lá fui pra Escola Normal, onde entrei pro Movimento Secundarista.

Bom, depois que eu entrei pro Movimento Secundarista a minha participação começou a ser política, e isso já começou a ser em 1968, né?! E aí eu já deixei muitas coisas porque já estava envolvida com a política. Aí depois eu acabei entrando para uma liga para-partidária, os partidos já estavam clandestinos por causa da ditadura, e tinha um partido clandestino que acabou surgindo que era a Ação Popular [AP]. A Ação Popular acabou derivando da Ação Católica Operária e Ação Católica Estudantil e se transformou num partido de linha marxista leninista, eles diziam, e eu acabei participando da liga, né?! É a questão 
do recrutamento, os estudantes começam a se organizar e os partidos vão lá e recrutam os estudantes.

Porém, eu participei da AP sempre com os meus questionamentos. Um dos meus questionamentos era que a AP discutia tudo menos a questão racial que eu sentia na pele, mas ninguém falava disso. Aí eu fiquei na AP até um período, até que ela, aqui no Pará, se fundiu com o antigo PCB [Partido Comunista do Brasil] e foi nessa fusão que eu saí. Eu saí exatamente na fusão. Eu lembro que eu fui super assediada pra voltar, o Paulo Fonteles não se conformava, me procurava lá onde eu ensaiava, mas eu decidi não voltar porque começou uma linha que não me agradava. Primeiro a ideia de que todo mundo tinha que se proletarizar sob uma ideia de ser proletário que, para mim, parecia muito caricatural. Era uma ideia muito fechada, parecia que tinha uma única forma de ser proletário e eu me opunha a essa ideia que se assemelha muito à ideia absurda de algumas pessoas de direita que acham que quem é de esquerda não pode ter iPhone. Contra essa ideia caricatural eu dizia que "mais proletária do que eu, eu duvido", então eu não queria me "proletarizar", eu só tinha um sapato! No dia que a molecada escondeu o meu sapato, enquanto eu jogava barrabol, eu enlouqueci atrás do sapato. Só saí dali quando eu achei o sapato. Esse sapato era pra ir pra escola, pra ir pra tudo quanto era lugar, imagina se eu chegasse em casa sem o sapato, era a morte! Então eu era muito pobre e eu ainda tinha que me "proletarizar" ainda mais? Mas nunca! Não era a minha vontade.

E ainda tinha um outro problema: eu aprendi a ler em inglês, não sei falar em inglês, mas aprendi a ler com dicionário, por causa da luta racial nos Estados Unidos. Eu achava lindo, Malcon X, os Panteras Negras, eram meus heróis e minhas heroínas. Foi lendo o que era produzido naquele momento, sobretudo nos Estados Unidos, no período da luta pelos direitos civis da população negra, que eu comecei a dar mais consistência política e também teórica aos ensinamentos de insubmissão ao racismo que eu tinha aprendido em casa, com a minha avó. Mas, isso era duplamente rejeitado pelo PCB porque o partido desvalorizava a discussão racial e tinha aversão à produção intelectual estadunidense por considerá-la imperialista. Eu mesma era contra o imperialismo dos Estados Unidos na América Latina, mas eu não podia deixar de lado a luta racial porque claramente ela não tinha caráter imperialista, mas sim libertador, justamente por ser antirracista, mas isso, naquele momento, não era compreendido.

Bom, acabou que eu saí e entrei numa organização que pelo nome eu pensei que corresponderia aos meus anseios de discussão da questão racial, que era a VAR-Palmares. Foi criada uma célula da VAR-Palmares em Belém e aí eu fui convidada e eu fui lá - mais tarde eu vim saber o porquê do nome Palmares, mas 
lá também não discutia a questão racial, tampouco a questão de gênero, isso não se falava, discutia quase tudo sobre classe, menos a questão racial e aí eu sentia muita falta de um lugar para discutir a questão racial. A VAR-Palmares acabou, muita gente foi presa, mas eu continuei.

E aí eu mergulhei de cabeça no teatro, ele passou a ser a minha tribuna, o lugar para problematizar as questões raciais, haja vista que eu não conseguia fazer nos partidos políticos. $\mathrm{O}$ teatro me ajudou muito nessa minha afirmação. $\mathrm{E}$, daqui a pouco, nessa arrumação, eu acabei conhecendo algumas pessoas que tinham os mesmos anseios que eu e, quando eu vi, eu já estava no Movimento Negro lutando pra criar o CEDENPA. Eu digo que nada disso foi proposital, as coisas foram acontecendo.

Nesse tempo eu já estava na universidade fazendo uma especialização, em 1976, e, em 1978, eu entrei pra cá como professora, sem deixar o CEDENPA ou o teatro. Eu acho que eu tenho que ter uma tribuna sempre. Em um determinado momento a minha tribuna passou a ser o movimento e fui largando um pouco o teatro, porque a gente viajava muito e isso me impedia de ensaiar, e acabei ficando apenas no movimento e na universidade. Mas eu ainda não tinha arranjado um jeito da universidade ser a minha tribuna, apesar de sempre ter me movimentado para lutar contra o racismo aqui dentro, o que é muito raro na universidade e, por isso, muitos me conheciam, me tinham como referência pra falar sobre racismo, mas eu ainda não tinha o amplo reconhecimento e o renome que eu tenho hoje. A universidade se tornou mesmo minha tribuna a partir do início dos anos 2000, com a minha participação na Conferência de Durban, em 2001, e o processo de reivindicação de cotas raciais na UFPA, encabeçado pelo GEAM, que foi criado por mim juntamente com outros professores e alunos, em 2002. Como parte desse momento, eu escrevi uma tese sobre movimento negro, ações afirmativas e cotas para negros na universidade.

E nessa eu estou até agora, eu não sei até quando eu vou ficar aqui na universidade porque daqui a pouco eu vou me aposentar ${ }^{5}$, afinal de contas eu estou velha, mas continuo aqui na luta, tentando fazer com que a vida fique um pouco melhor. A gente tem retrocessos, tem avanços, mas a gente não desiste.

Alef Monteiro: É notória a melhoria quantitativa e qualitativa na presença de estudantes negros nas universidades brasileiras por causa de políticas públicas e mudanças nas legislações desde os anos 2000. Considerando a inexistência dessas, na década de 1970, como foi ser uma estudante negra, na UFPA, nesse período?

\footnotetext{
No momento da entrevista, Zélia ainda não tinha sido laureada com o título de Professora Emérita da UFPA.
} 
Zélia Amador de Deus: Naquele tempo, como hoje, não era fácil, para uma mulher preta e pobre, manter-se na universidade, por isso, eu tive que trabalhar para poder continuar estudando. Eu terminei o nível Médio (à época, Curso Normal), parei um ano e fiz concurso para a Escola Salesiana do Trabalho. Fui aprovada, comecei a dar aula e no ano seguinte eu ingressei como estudante de graduação na UFPA.

Fiz o curso inteiro militando, naquele período eu tinha militância clandestina. Todo o curso de Letras, de 1971 a 1974, eu fiz militando clandestinamente. Mas eu tinha uma vida "tranquila", não cheguei a ser presa ou ter que viver em clandestinidade, como alguns de meus colegas de militância. Minha vida, na época da graduação, sempre foi bastante ocupada: eu fazia teatro, fazia o curso, militava clandestinamente e ainda dava aula de manhã, na Escola Salesiana do Trabalho.

Eu fiz Letras e me dei muito bem. Eu fiz porque adorava ler, adorava literatura e considero ter me dado bem porque, como as pessoas diziam, eu só tirava "notão", e assim as pessoas me aceitavam. Mas acho importante marcar que eu me firmei em sala de aula, desde o primário, como aquela preta que só tirava nota boa, então, essa era a minha marca. As pessoas diziam: "não te mete com ela porque ela é CDF". Eu nem julgo que realmente eu o fosse, mas, eu tinha essa fama. E, com essa fama, eu continuei no ensino superior.

Logo, não é que a minha turma me aceitasse, a minha fama fez com que eu fosse tolerada e ao mesmo tempo servisse como aquilo que o humor chama de "preta ostentação". Eu era a preta (e não qualquer preta, mas a preta inteligente) que tornava possível o argumento retórico: “eu, racista?! Eu até sou amiga da Zélia!" [Risos]. Entendeste?! Eu entrei na universidade depois, como professora, e a situação permaneceu. Eu era a única aqui, a única ali, quer dizer, uma exceção que confirmava a regra. Mas, para o mito da democracia racial, estava resolvido: eu era a prova de que o negro estava na universidade, de que negros e brancos estavam nos mesmos lugares quando, na verdade, bastava um olhar crítico para ver que eu era a única negra em meio aos brancos nos espaços que para eles era, antes de tudo, privilégio.

Eu nunca esqueço da vez que dei uma entrevista a um linguista holandês que passou por aqui. Eu estava junto com uma amiga minha de Letras, da língua estrangeira, e aí eu disse pra ele como era a questão racial aqui, ele estava pesquisando isso. A minha amiga me olhou horrorizada, acho que ela nunca pensou que eu pensasse aquilo. Ela disse: "não, mas também não é tanto assim". Ela achou muito pesado o que eu estava dizendo, então eu respondi a ela: "como não é? Não é pra ti que não sente, mas pra quem sente, é!”. E assim foi. Eu acho 
que acabei virando, na universidade, em algum momento, a "preta de estimação" que pode ser ostentada quando alguém é pego em atitude racista: "racista, eu?! Até sou amiga da Zélia! / Eu até conheço a Zélia!”. E eu sempre lutei pra não ser uma "preta ostentação", mas mesmo assim algumas pessoas me adotaram como "preta de estimação" e eu até sei quem são essas pessoas, mas enfim [risos], agora não vem ao caso.

Na minha sala havia apenas duas negras, eu e a Manuelina. Por coincidência, nós éramos o protótipo das duas formas da mulher negra ser aceita, ou melhor, tolerada, na sociedade brasileira. Quando eu entrei na universidade em 1971, eu já fazia teatro, então a minha figura - de preta que afirmava sua negritude - era relativamente aceita porque eu era de teatro. Eu andava com um Black imenso e, como eu era de teatro, as pessoas pensavam: "ah, é artista, é doida, então pode", né?! E somava-se a isso o fato de, mesmo sendo a "artista doida", eu estar entre os alunos da classe com rendimento acadêmico mais alto e também já ser professora. Desse modo eu estava acima da média da turma, entendes? Eu fui relativamente aceita, e assinalo, relativamente, porque eu era uma aluna excelente. O bom é que eu era, mas porque eu tinha facilidade com as matérias estudadas, e não porque eu me esforçasse para dominar os assuntos a fim de ser aceita.

No meu caso, quanto a isso [domínio das matérias], não foi difícil, mas não é assim para todas as mulheres negras. Algumas pessoas têm mais dificuldades para lidar com as matérias acadêmicas e outras não. Isso, porém, é um problema maior para nós, mulheres negras, porque somos "naturalmente" rejeitadas pela sociedade e se destacar nas mesmas atividades feitas pelas brancas é uma forma de ser aceita: "ela é preta, mas é muito inteligente; é preta, mas é muito competente". É sempre esse "mas..." que é valorizado e não o fato de ser negra, ser mulher, ser gente, oras! E, assim, mesmo não gostando de quem tu és por causa da tua cor, do teu gênero e da tua classe as pessoas passam a te respeitar porque te destacas naquilo que elas fazem. Esse é um mecanismo perverso que exclui ainda mais as mulheres negras que, por serem mais atingidas pela desigualdade social, muitas vezes ficam impossibilitadas de ter um rendimento acadêmico de excelência. Sem um rendimento maior que as mulheres brancas, na mesma atividade, as mulheres negras são, no mínimo, triplamente excluídas.

Quanto à Manuelina, eu lembro que ela era tímida, quietinha no canto dela, éramos as duas únicas negras na turma. A postura da Manuelina é aquela que torna a relação entre negros e brancos racistas uma relação não flagrantemente conflituosa porque ela não contesta, de modo contundente, o papel de passividade e subserviência que se espera do negro. 
Alef Monteiro: Como se deu sua inserção no campo das artes e dos estudos literários?

Zélia Amador de Deus: Eu sempre fui apaixonada pelas Artes! Minha inserção no campo das Artes se deu por causa do gosto que eu tinha por leitura e por literatura. Desde criança eu gostava de ler e também desde criança eu sou fascinada por apresentações musicais e teatrais. Em minha infância, assistir às apresentações de Boi-Bumbá era algo muito prazeroso e meu sonho era ser Catirina ${ }^{6}$. Mais tarde, durante a minha juventude, cheguei ao teatro, onde trabalhei tanto como atriz, quanto como diretora. E foi por esses dois campos das Artes Literatura e Teatro - que fiz minha trajetória.

Em meu percurso acadêmico, como eu já gostava de Literatura, eu também fiquei apaixonada por Teoria da Literatura a ponto de ir estudar no mestrado. Mas, ao mesmo tempo em que eu gostava de Literatura, eu sabia que Letras era um dos lugares mais difíceis de você introduzir a discussão das questões raciais dentro da universidade. Na verdade, eu sempre disse que são dois campos difíceis nas humanidades: Letras e Pedagogia (Educação). Então foi minha paixão por Literatura e depois por Teoria da Literatura que me levou a esse campo que me fora aberto profissionalmente pela minha formação em Letras.

Mas, aqui na UFPA, eu acabei chegando à docência e pesquisa no curso de Letras não pelas Letras em si, eu fui contratada pra trabalhar com Arte, porque o curso de Letras oferecia disciplinas eletivas dentre as quais estava História e Teoria do Teatro, e quem dava essa disciplina era uma professora que se transferiu para o Rio de Janeiro deixando vaga a cadeira dessa disciplina, então, eu acabei vindo pra cá e ocupei essa vaga pra trabalhar com teatro. Quando os departamentos se separaram, eu acabei ficando no Departamento de Arte, pois História e Teoria do Teatro saíram do currículo de Letras. Então, eu não era das Letras propriamente dita, nunca fui, eu era sim das Artes. Aí comecei a trabalhar, além de História e Teoria do Teatro, com Estética e História da Arte.

Alef Monteiro: Em 2019 a senhora completou 41 anos de docência na UFPA e é uma das primeiras professoras negras em uma atividade ainda predominantemente branca. Nesse sentido, relate alguns episódios que considere conveniente acerca do seu enfrentamento ao racismo institucional.

\footnotetext{
No auto do Boi-Bumbá, Catirina é uma negra escravizada que durante sua gestação tem o desejo de comer a língua do boi mais querido pelo senhor da fazenda. Seu esposo, Chico, respeita o "sagrado desejo de grávida" de sua esposa e sacrifica o boi removendo-lhe a língua. Essa ação dá início à saga de morte e ressurreição do boi.
} 
Zélia Amador de Deus: Olha, o racismo, esse, que fica camuflado, quietinho, em latência, ele está a qualquer momento pronto a se manifestar em toda a sua potente violência. Quando eu me candidatei a diretora do Centro de Letras e Artes da UFPA, do qual fui diretora de 1989 a 1993, foi o primeiro embate crucial que tive contra o racismo nessa universidade. Nessa ocasião pipocaram discursos discriminatórios de cunho étnico-racial para deslegitimar a minha candidatura.

Mas o pior foi quando eu ousei ser candidata a vice-reitora, no ano de 1992. Alguns dos apoiadores da chapa oposta organizaram uma apresentação teatral no ginásio da UFPA, e, nessa peça, eu fui retratada como a Cheeta e o Marcos Ximenes Ponte, que é nordestino, foi retratado como cangaceiro. Então, esses dois episódios eu considero os mais alusivos do racismo institucional que enfrentei na UFPA, enquanto docente, mas esse segundo episódio, sem dúvidas, é o mais simbólico. Eu digo que ele foi a marca do racismo que imperava e ainda está fortemente presente nesta universidade. Para desespero dos racistas, a nossa chapa ganhou e fomos reitor e vice-reitora entre os anos de 1993 e 1997.

Alef Monteiro: Como a senhora avalia a visibilidade atual da população negra amazônida no campo dos estudos afro-brasileiros?

Zélia Amador de Deus: Nos últimos anos estão aparecendo muitos estudos sobre as populações afro amazônicas e eu fico super feliz por isso. Sem dúvidas, o crescimento de pesquisas se dá ao fato de que muitas pessoas negras acessaram a universidade e estão produzindo trabalhos sobre as mais diferentes dimensões e aspectos da vida das populações negras locais. Todos esses trabalhos firmam ainda mais os avanços da luta que vem sendo travada há muito tempo pela militância negra e por vários pesquisadores contra o apagamento da presença africana, e atualmente afrodescendente, na Amazônia. A população negra amazônida hoje é inegavelmente visível e essa visibilidade dia após dia se torna mais nítida no campo dos estudos afro-brasileiros, mas há muito ainda a ser feito, pois essa visibilidade ainda não ocorre do mesmo jeito na sociedade brasileira que ainda preserva em sua mentalidade a crença da ausência negra na Amazônia. Logo, precisamos fazer com que o conhecimento produzido não fique restrito ao círculo dos especialistas ou ao ambiente acadêmico.

Eu tenho participado de várias bancas que examinam estudos em que a temática étnico-racial tem vindo à tona, e não apenas ligada à população negra, mas também aos povos indígenas. Recentemente eu participei da banca de dissertação de mestrado de um indígena cujo trabalho é uma insurgência! Fantástica! Eu vibro com isso. É isso que a universidade ganha com a entrada desses grupos aqui. Quem 
ganha é a universidade, quem ganha é a sociedade que se privou disso o tempo inteiro por causa do racismo. E, agora, temos que garantir que esse conhecimento continue a ser produzido e alcance a população em geral.

Alef Monteiro: Quais são, a seu ver, os temas emergentes e mais relevantes para as pesquisas sobre negros(as) na Amazônia?

Zélia Amador de Deus: Olha, eu acho que primeiro a gente tem que ver que o negro na Amazônia é invisibilizado. Esse é um tema perene e que, infelizmente, ainda não foi superado. Todo o resto do país acha que aqui não tem negro. A imagem que foi vendida da Amazônia é indígena e até aqueles lugares que possuem heranças indígenas, mas que também são negros, como é Belém, a imagem vendida é do caboclo, é do moreno. Tanto que Belém é a "cidade morena", "moreno" é o sintoma de embranquecimento de uma cidade que sempre teve muito preto. Então, esse ainda é um tema relevante, pois ele foi construído em várias etapas e possui muitas camadas que ainda precisam ser examinadas.

Outro tema emergente que eu destaco é o processo de colonialismo interno que pesa sobre a Amazônia. A Amazônia foi e é colonizada pelo Sudeste e Sul do país, e por isso esse processo a torna desigual em relação a essa parte do Brasil. Esse é um tema que pode não parecer tão novo, porém, a novidade está em atentar para uma dimensão que por muito tempo foi ignorada: Amazônia foi tornada desigual em um processo de colonialismo interno porque ela foi e é racializada, e eu acho que a gente tem que enfrentar essa questão da desigualdade regional considerando a racialização da região e eu acredito que novos estudos podem achar esses caminhos.

Alef Monteiro: Como a senhora avalia o Movimento Negro paraense até a atualidade?

Zélia Amador de Deus: Antes de tudo, é preciso que se saiba que o Movimento Negro é muito antigo e possui várias formas. Não existe um Movimento Negro como se fosse um coletivo monoliticamente organizado. O Movimento Negro é variado e existe sob vários formatos. O único elemento em comum entre as várias formas de Movimento Negro ao longo do tempo tem sido a instrumentalização da cultura como ferramenta de luta contra a opressão racial. Isso é, digamos assim, o que une esses movimentos de tal forma que seja possível falar em um todo, mas fora isso, existem diversas configurações. Por exemplo, hoje existe o Movimento Quilombola, os quilombolas são uma forma de Movimento Negro; as pessoas de matriz africana reunidas, discutindo, organizando-se e lutando pela 
vida são outra forma do Movimento Negro; o pessoal da capoeira são outra forma do Movimento Negro, enfim, existem várias formas e vários campos de atuação do Movimento Negro.

Agora, a partir de 1978, surgiu essa forma de Movimento Negros que eu estou inserida, digamos assim, que é mais político-reivindicativa, no sentido de lutar por políticas públicas de combate ao racismo e eliminação da discriminação racial. Mas o Movimento Negro antecede a década de 1970, e a população negra está organizada nessas várias formas já destacadas em que cada um combate do jeito que pode e do jeito em que mais se alinha. Eu sempre me alinhei nessa corrente de lutar pelo combate ao racismo e eliminação da discriminação racial, mas isso é uma opção minha que não é mais ou menos legítima que qualquer outra corrente.

E mesmo essa forma de movimento negro que surgiu a partir de 1978 não é única. A minha experiência de CEDENPA mostra isso, o CEDENPA é múltiplo. Um bom exemplo dessa multiplicidade na corrente que luta por políticas públicas de combate ao racismo e eliminação da discriminação racial é a segmentação (que na verdade é uma multiplicação) ocorrida após a Marcha das Mulheres Negras, de 2015. A Marcha teve um efeito na juventude negra que originou vários coletivos de mulheres negras.

Semelhantemente, a chegada de negros à universidade criou $n$ coletivos dentro das universidades brasileiras. Aqui, na UFPA, isso foi muito forte. Já não estou sentindo tanto a presença desses coletivos, eles já foram mais ativos aqui, porém, no Brasil todo existem vários coletivos nas universidades discutindo o racismo, o epistemicídio, a diáspora e eu acho isso fantástico. Então, a avaliação que eu faço do Movimento Negro no Brasil e mais particularmente no Pará, no geral, é positiva, sobretudo pela contínua e cada vez mais diversa reinvenção da qual esse movimento é capaz.

Alef Monteiro: Qual o lugar do feminismo ciberativista nas reflexões sobre a vida da população negra, e, em particular, das mulheres negras?

Zélia Amador de Deus: Olha, o processo preparatório pra Marcha das Mulheres Negras de 2015 se deu principalmente pela internet. E eu percebo que desde lá elas continuam em marcha no ciberespaço. E, claro, vale lembrar que as mulheres negras estiveram e estão sempre em marcha, de modo que já existiam mulheres negras na internet falando sobre o racismo que as oprime, porém, o processo de organização da Marcha demonstra a consolidação de uma nova frente para a militância organizada fixando, assim, nesse espaço, a presença individual e institucional das mulheres negras. Nessa frente nós também temos nos expandido e eu acho isso fantástico porque, uma coisa que eu sempre falo, é que todos os 
espaços podem se transformar em tribuna de luta, inclusive a internet. Eu vejo que as mulheres negras ocupam esse espaço e umas ocupam muito bem.

Nesse sentido, acredito que o ciberativismo pode dar uma contribuição pelo fato de disseminar conversas, discussões sobre o racismo - pro bem ou pro mal - o que é importante porque, no Brasil, o racismo sempre foi um tema tabu. Não faz muito tempo que os dicionários brasileiros contêm o vocábulo "racismo", não continham. E agora que nós conseguimos mudar isso e podemos também usar outros meios para falar, acho que temos que falar do racismo o tempo inteiro. O racismo sempre se fortaleceu pelo silêncio e agora quanto mais a gente falar, mais a gente tem possibilidade de enfraquecê-lo, de trazê-lo à tona, de mostrar que a gente está numa sociedade racistas e que esse racismo não é só o racismo individualista de pessoa contra pessoa. Esse racismo passa pelas resoluções das instituições, esse racismo passa por todas as estruturas existentes nas sociedades que foram colonizadas. Então temos que falar muito dele, e é isso que as mulheres negras que estão na internet fazem, elas ajudam a fazer esse papel de provocação e reflexão.

\section{ALGUMAS PALAVRAS DO ENTREVISTADOR À GUISA DE CONSIDERAÇÕES FINAIS}

Para se manter, toda saga de resistência precisa de um ou de vários heróis. Mais do que produção da fantasia, o herói desempenha funções sociais. No âmbito real, é uma liderança que gasta sua vida na tentativa de materializar uma utopia $^{7}$ e, para isso, realiza ações e mobilizações no campo sociocultural e político. No nível ideal, e mais precisamente psíquico, o herói é um elemento importante para a construção da subjetividade e da identidade. Essa é uma importância ímpar para grupos subalternizados, como a população negra ${ }^{8}$. Considerando a sociedade brasileira, que historicamente pratica o genocídio dos negros através do extermínio físico e da miscigenação (NASCIMENTO, 2016) - nesse último caso, destruindo também os negros de dentro para fora, pois, a miscigenação opera também no nível da cultura e da psiquê - a existência de personalidades negras que deem corpo a heróis da luta antirracista é uma necessidade.

Falo em utopia no sentido desenvolvido por Karl Mannheim (1972). Para esse autor, a ideologia é uma ideia que não condiz com o real, pois é a inversão da realidade a fim de mascarar, no âmbito das ideias, a violência e exploração reais. Em contrapartida, a utopia também não busca ser uma representação do real, mas sim uma proposta de superação da violência e exploração que se apresentam no mundo real. A utopia reconhece o real e o nega não por meio do mascaramento, mas da proposta de superação. É a utopia que serve como embasamento nas lutas dos grupos minoritários.

8 No que diz respeito às implicações da representatividade, por meio de figuras públicas negras, na subjetividade da população negra no Brasil, as explicações reunidas por Noemi Kon, Cristiane Abud e Maria Lucia da Silva (2019) estão entre as mais esclarecedoras. 
No Brasil e, em particular, na região Norte, Zélia Amador de Deus notoriamente é uma heroína da luta antirracista. Sua trajetória de vida pessoal e acadêmica atestam seu compromisso com o combate do racismo, e ensinam muitas lições. Sua insubmissão desde a infância indica a importância de se ensinar às crianças o gosto pela liberdade e por uma consciência negra acompanhada de posturas antirracistas. A vida de Zélia é, em si, um testemunho do enfrentamento ao racismo estrutural da sociedade brasileira em geral à universidade, e nos provoca à reflexão sobre que universidade queremos, que grupos políticos queremos, que movimento negro queremos, sobretudo se considerarmos as muitas possibilidades abertas, os temas que faltam ser estudados ou aprofundados, ou, ainda, o pêndulo de avanços e retrocessos salientado por Zélia na entrevista.

“Aquele que aprende, ensina?' - Provérbio africano.

\section{REFERÊNCIAS}

AMADOR DE DEUS, Z. Ananse tecendo teias na diáspora: uma narrativa de resistência e luta das herdeiras e dos herdeiros de Ananse. Belém: Secult-Pará, 2019.

ANZALDÚA, G. Falando em línguas: uma carta para as mulheres escritoras do terceiro mundo. Estudos Feministas, Florianópolis, v. 8, n. 01, p. 229-236, 2000 .

ANZALDÚA, G. Como domar uma língua selvagem. Cadernos de Letras da UFF, Niterói, n. 39, p. 305-318, 2009.

GONZALES, L. Racismo e sexismo na cultura brasileira. Revista Ciências Sociais Hoje, São Paulo, v. 4, p. 223-244, 1984.

KON, N. M.; ABUD, C. C.; SILVA, M. L. (org.). O racismo e o negro no Brasil: questões para a psicanálise. 2. ed. São Paulo: Perspectiva, 2019.

KOPENAWA, D.; ALBERT, B. A queda do céu: palavras de um xamã yanomami. São Paulo: Companhia das Letras, 2015.

MANNHEIM, K. Ideologia e utopia. Rio de Janeiro: Zahar, 1972.

NASCIMENTO, A. O genocídio do negro brasileiro: processo de um racismo mascarado. 3. ed. São Paulo: Perspectiva, 2016.

SPIVAK, G. C. Pode o subalterno falar? Belo Horizonte: Ed. UFMG, 2010. 
